\title{
Recommendations for Ukraine on Introduction of Information Democracy
}

\author{
Zalecenia dla Ukrainy \\ w kwestii wprowadzenia demokracji informacyjnej
}

\section{- Abstrakt •}

Artykuł bada proces optymizacji demokracji informacyjnej w Ukrainie. Wśród obszarów problemowych, które rozwiązać może demokracja informacyjna znajdują się: zwiększanie zaufania publicznego do rządu, legitymizacja rządu i społeczne zrozumienie władzy politycznej, interesów obywateli i służb publicznych, równy dostęp do procesu politycznego, skuteczna reprezentacja $\mathrm{w}$ procesach decyzyjnych $\mathrm{w}$ sprawach politycznych i administracyjnych, uczestnictwo obywateli poprzez ich zaangażowanie w tworzenie polityki przy pomocy konsultacji publicznych i debat. Doświadczenie w ustanawianiu narzędzi demokracji informacyjnej w Ukrainie pokazuje, że przez zastosowanie technologii internetowych tworzone są nowe możliwości uczestniczenia w procesie politycznym dla obywateli, a w szczególności zwiększania ich świadomości dotyczącej ważnych kwestii politycznych państwa i władz lokalnych.

Słowa kluczowe: demokracja informacyjna, optymalizacja, platforma internetowa, władza, rząd, możliwości

\section{- Abstract •}

The paper researches the optimization process of information democracy in Ukraine. The problems, which can be solved by information democracy include: increasing public confidence in the government, the legitimacy of the government and public understanding of power, the interests of citizens and public services, equal access to the political process, effective representation in the decision-making processes in political and administrative matters, and participation of citizens through their involvement in policy-making through public consultation and debate. The experience of implementing IT tools of democracy in Ukraine shows that through the use of Internet technology people gain new opportunities to participate in the political process, in particular, increasing their awareness on important political issues of the state and local authorities.

Keywords: information democracy, optimization, inetrnet platform, information, power, government, opportunity 


\section{Introduction}

The collapse of the Soviet Union and the collapse of the socialist bloc led to an unprecedented increase in the number of countries that have declared themselves democratic. In the early 1990s, many were convinced of the rightness of F. Fukuyama who prophesied the "end of history" in connection with the collapse of the communist regimes and proposed a global celebration of liberal democracy and market economy. A new wave of democratization has to cover the entire postSoviet Eurasia to solve the problem of expansion of European civilization in the short term (Kulyk, 2011). But the thesis of the "end of history" could not stand the test of time. Not only is the promotion of democratic principles and liberal ideas of stalled but also there is doubt if these criteria declared in the constitution are actually realized (Samolovov, 2012). Various challenges and threats to CIS member states encouraged them to develop the most appropriate response mechanisms. As a result, the former Soviet Union has developed various models of the political system.

\section{Analysis of the Recent Research}

The general condition of development issues as information in the modern media and political world can not be called poor, since in many scientific studies specialists take into account the value of information for political processes. Among the scientists who studied the issue of information democracy in the modern sense of the term are the following specialists: Zh.-A. de Condorcet, R. Dahl, J. Nesbit, G. Maklyuyen, L. Hrosmann, A. Toffler, J. Schneider, S. Hanktinhton, J. Beshler, T. Karl, J. Keen, A. Leyphart, H. Linz, S.Lipset, H.O 'Donnell, A. Przewor, D. Rastou, G. Sartori, G. Haywood, G. Erme, A. Melville, J. Nysnevych, N. Baranov, M. Vershinin, M. Shapovalenko, Pocheptsov, V. Pantin, A. Salmin, L. Smorgunov, and many others.

\section{Methods}

To attain these objectives, we used a number of general, social, humanitarian, and especially scientific, strictly political, methods and methodological approaches. The paper used techniques such as systematic, interdisciplinary, comprehensive, comparative, historical, and others. At the same time, it involved other methods 
that have not yet been widely used in the study of problems of information democracy and political aspects, including: political science, civilization, world-systemic, synergistic, critical and constructive et al.

The purpose of the article is to analyze the conceptual foundations of optimization processes of the information democracy in Ukraine.

\section{Objectives and Problems of E-Democracy}

Without going into debate on the future of representative democracy, it should be noted that the introduction of ICT in the structure of the interaction of the public authorities creates added social value, enabling and enhancing direct participation of citizens in the policy-making process. As D. Lenihana aptly phrases, "ICT can be used to enhance public space paths that will promote consultation and dialogue between citizens and their governments. Through this dialogue, citizens and stakeholders can identify their views, offer ideas, identify differences or take a more overt part in the decision making process, i.e. in governance. They can make a significant contribution possible to excite and enhance the legitimacy of democratic government" (Donald, 2002). Democracy has proven its extraordinary vitality and resistance as a form of governance through the centuries of human history. A less constant in its long history is the technique of democracy: "specific mechanisms to translate its essential principles into daily practice of voting representation, decision-making, implementation and compliance by citizens and officers who have changed significantly and perhaps permanently".

A number of systemic problems interfere with compliance with information rights and freedoms of Ukrainian citizens. These are in particular (Gnatyuk, 2012):

- Lack of mutual communication and the triangle "society - media - power," although it is this communication that is the basis of the existence of any developed democracy. Despite the positive trend of press freedom in Ukraine amid global indices and intensive development of the national information sphere, an increasing percentage of our citizens feel isolated despite the access guaranteed by law to "open, accessible, objective, complete and accurate" information about the social life and activities of the public authorities.

- The monopolization of media markets. First of all, it concerns the broadcasting market which is already divided between the four large and several smaller media groups, and - to a lesser extent - the press market. These processes objectively narrow a "window of opportunity" for the entry of new 
actors and the media, and therefore, the realization of the constitutional right to freedom of expression and information.

- Lack of the public broadcasting sector, i.e. public counterbalance to the private media, designed to provide a balanced, dual nature of the national media system. World experience shows that the developed structure of public broadcasting is an essential element of modern democracy.

- Insufficient professional level of Ukrainian journalism, lack of corporate ethics. This situation ultimately has a negative impact both on the quality of the domestic media products and the consolidation of Ukrainian media freedom of expression, objectivity, and commitment to the public interest.

- Politically biased and negative reports in the information space of Ukraine. One reason for these phenomena is the lack of social responsibility of the media, a partial awareness of their own social function.

- Uneven and unequal conditions of access to information in different regions, i.e. the presence of areas of low informational content and "white spots" on the information map of Ukraine due to a lack of capacity and the number of national broadcasting transmitters.

- Delays and difficulties in the transition to digital broadcasting, which occur due to: a) a lack of a sufficiently effective and consolidated action plan, b) inconsistent activities and competencies of authorities in this matter, c) insufficient mechanisms to ensure the population's means of receiving digital broadcasting signals, d) a lack of awareness about its features and benefits.

An analysis of legislation and other documents allows to identify the following factors that threaten the formation of information democracy in Ukraine:

1. Introduction of political censorship. The authorities are trying to keep political censorship in the print, audiovisual and electronic media, and in the Internet at the national and regional levels. This is contrary to democratic change in society as it restricts citizens' rights to receive and disseminate information and creates the world's image of Ukraine as a non-democratic state.

2. Different kinds of pressure on the media. The media are affected by economic sanctions and selective financial support from the state. High taxes, high price of paper, monopolization of certain types of information services, limited advertising market and investment, and low purchasing power of the population are causing difficulties for the majority of the non-profit media, especially those with social and political orientation (Concept, 2001).

3. Manifestations of political extremism against journalists. There are manifestations of political extremism in the form of physical violence against jour- 
nalists, attacks, and deaths not disclosed by law enforcement. It creates fear in the society, hinders democratization of the social life, and creates a negative image of Ukraine in the world.

4. Lack of transparency of the government. Information society places new demands on the public authorities, which is associated with the transition from a command to the democratic functioning of the option in the "power - the media".

We believe that an open government as an axiom is the key to protection from the negative effects of manipulation by the mass media.

The need to create opportunities to achieve sufficient information for decision-making by public authorities, citizens, civic associations, and other legal entities in Ukraine and to guarantee the freedom of information, access to information in a national information space of Ukraine, and full development of the information infrastructure is the aim of the draft Law On Information and Cyber Security, Sovereignty Ukraine (Project L. Lukyanenko, 2003), which was submitted to the People's Deputy of Ukraine L. Lukyanenko.

5. Convert the mass media propaganda and manipulation. The emergence of new information products in the country is almost always clearly focused on the tasks of a political nature in the interests of the founders or financial groups, which focus on the current government. Virtually all the media are distributed among influential financial and political circles. If the information function is minimized, news becomes propaganda. The media, as an important element of political capital, allow financial and political factions to spread biased information, impose self-censorship of journalists, reducing their social status, and cause other negative phenomena.

Regional surveys show that most of the media cannot be considered independent, financially independent publications, mostly because the founders the Volyn media are government and local governments. Today still a large number of the mass media are state and municipal. Although there are rare examples - both at national and regional levels - of the media as successful projects, the media are considered as an instrument of political manipulation (Klimenko, 2006, p. 210).

\section{Organizational Task of Introducing Information Democracy}

The main organizational problems in the implementation of democracy include the following obstacles (The Law of Ukraine 2003, p. 7-9): 
- Development of unified and standardized technologies for collecting, documenting, processing, and converting information into electronic form, input, computer processing, given the rules and algorithms, search and delivery of information on request in the government system, using advanced computer information technology and geographic information systems;

- Provision based on modern information technology, international standards, unified system of classification and coding compatible interaction and integration of creation, updating, maintenance and use of government information resources, regardless of their departmental affiliation or ownership;

- Development of technologies for interaction between government agencies as soon as possible and complete services for citizens and NGOs;

- Licensing of public and private organizations to develop and implement uniform technology and standardized method of input, processing, updating, storing, and delivering information to ensure efficiency, quality, low cost, and speed of work;

- To ensure comprehensive protection of information resources by using effective tools and techniques to protect information from unauthorized access, accidental or willful damage and distortion, forgery, blocking the organization of appropriate levels of access for different categories of users;

- Organization of monitoring, control, integrity and use of the information base of "e-government";

- A network of state, public, and private offices to provide Internet access for the general public;

- Interaction of the "e-government" information system with international and domestic electronic banking systems;

- The implementation of organizational changes in government structures to adapt them to the conditions of the "e-government" information system.

Recognizing the need for information democracy, it should be understood that the above refers to the computerization of all administrative processes in government agencies at all levels to create a computer system that can support all of these functions and interact with the public and businesses. It will not be possible to implement on-line services, such as receiving tax returns or issuing certificates if the administration is not automated or unable to process electronic documents (Baranov, 2002). 


\section{The Problem of the Digital Divide and Digital Literacy}

Prospects for democracy are directly determined by the level of development of information society in the country, the level of computerization of the population, and Internet access. As "digital divide" we understand a new kind of social differentiation, which is mainly due to different capabilities using the latest IT technology. These values indicate insufficient development of the infrastructure in Ukraine.

Ukraine still retains one of the lowest figures in Europe regarding public access to the Internet - now it is 17.8 users per 100 inhabitants. For comparison, Greece has the lowest Internet coverage among the EU states - 20 users per 100 inhabitants (Draft report 2009).

There are strong regional inequalities in Internet access. In the Kiev region live $58.89 \%$ of the general number of users, in Odessa $-6.85 \%$, Dnepropetrovsk $5.32 \%$, Donetsk $-5.02 \%$, Kharkiv $-4.70 \%$. Other regions accounted for $10.28 \%$ of users. Least of all Internet users are recorded in the Zhytomyr region $-0.25 \%$, Chernivtsi region $-0.22 \%$, and in the Volyn region $-0.11 \%$ (Draft report 2009).

Providing secondary schools with computer equipment and Internet access also suggests maintaining interregional "digital divide." For example, if the index level of school computer classes in the whole country is $93 \%$, in the Ternopil region it is $54 \%$, Khmelnitsky $-57.9 \%$, Lviv $-75 \%$. Only $42.7 \%$ of secondary schools are connected to the Internet (Draft report 2009).

Computer literacy can be improved by the efforts of high schools. Computerization of schools, the educational process must be, among other things, the quintessence of the current school reform. Preferably the introduction of information and multimedia technologies in educational process in all school subjects, not just to organize computer classes in schools (Baranov, 2002).

The current rapid progress of information technologies requires a new quality of educational services to ensure a decent standard of training in various areas of society. The labor market puts much higher requirements for university graduates in the modern Ukraine. The quality of education has a direct impact on the development of informational democracy in our country, since free information and unhindered access to information resources are the foundation of progress. Thus, we can say that quality education through free access to global educational resources can help the development of democratic values in Ukraine.

In our opinion, informational and educational activities in the country are interconnected. Informational activities perform an educational function: they impact identity formation, formation of ideology, a system of values in each in- 
dividual, and education. The development of information democracy is primarily responsible for specialists in the field of journalism and information-processing activities. In this regard, there is a major problem - the question of qualification of information institutions.

Improving the quality of knowledge and training of experts promote the transparency of the authorities, which in turn provides the democratization of the country. In addressing this issue the following aspects should be taken into account (Mytko, 2010):

- The need to increase the level of professionalism of by changing the system of journalists' education;

- Use methods of "soft power" based on popular culture and ideas informing "free men";

- The lack of a clear system of education information dealing with foreign mass media and the public, resulting in a negative image of the country as a whole;

- The need for a scientific discussion on the problems of the formation of knowledge in the field of information.

- In addition, the formation of high-quality knowledge in the field of information activities can be improved by observing the experiences of other countries in education (Khmelnitsky 2007), such as:

- - Using methods such as self enrollment of students with tuition, fundraising, and private sector sponsors (Russian Federation);

- - Increasing the autonomy of universities in defining courses, programs, and training techniques (UK), governments departments (Germany) and the right to enter university when needed but overall, also additional requirements for applicants (Spain);

- The establishment of universities with an individual approach to the criteria of payment, depending, for example, on family income and personal achievements of students (Italy);

- Bilateral agreements with other countries on the recognition of educational documents (Germany, Poland);

- Ensuring graduates a permanent job, providing a high quality education (France);

- The creation of a large university, which will become the main foci of basic science (UK, USA). 


\section{Process Optimization and E-Democracy}

A person cannot be an expert on many issues; however, in the real world a nonelectronic voter must have one representative in all matters. In information democracy we go around this limitation by using matrix delegation mechanism. In this situation, for each item at each level of government, or we can make decisions independently or to attract other people to be their representative, or delegate their votes. Information democracy is neither direct nor representative - it takes the best features of both these models.

A necessary condition of information democracy is the so-called "forced honesty". Corruption is a very serious illness of the society, but even this is treated by the formation and development of civil society and free media. Censorship and control of the media: there are free elections, but the press is completely controlled by government structures. The ruling party uses all available information resources to retain power and prevent opponents delay votes. The presence of censorship is often justified by the protection of the public order and "good manners." This situation can develop in two ways: either the civil society can successfully eliminate the state monopoly on information or there is a further pullback towards a one-party system (Samolovov, 2012).

All these models of illiberal democracy can fuse with each other (in developing countries who have recently stepped onto the path of democratization, usually this is what happens). In this case, the future of the democratic system is endangered. This cannot be a flexible and adequate political system simply because a genuine democracy requires appropriate economic, informational, and legal infrastructure that will ensure transparency and equality of opportunity (Samolovov, 2012).

A strong authentication citizen information system of democracy is a necessary and sufficient condition that ensures the possibility of legally significant electronic voting. Existing cryptographic protocols can do the following: ensure that, on the one hand, it is impossible to track who votes and, on the other hand, provide an opportunity for each voter to see the outcome of his engagement, ensure total transparency and protection against possible retaliation. In fact, the publicity of all communications between the citizens should be the main bulwark against corruption and tyranny. Meanwhile, the reduced space of secrecy pertains not only to public persons but also to the entire state and the entire system of international relations. The situation with the publication of secret documents on the portal WikiLeaks takes us to a new level of world politics. The next stage is transparency in international relations and honesty in discussing critical issues. If people do not 
like something in politics, including internationally, they now have the opportunity to state it directly, personally, on the pages of their websites and blogs.

Whatever strict chain of command is created, it will be unstable without the horizontal linkages at all levels. But such a structure over time will inevitably remain one for all network where vertical relations either completely disappear or become symbolic and each person has an opportunity to get some information about everyone with whom he meets. So we are not talking about some honesty forced "top-down", we are talking about recognition of the fact that in a network society that is being formed before our eyes, it occurs as a side effect. Moreover, this is the reality right now.

In the model of information democracy, voters choose representatives for each of the important issues, and are not able to delegate their vote to anyone. In choosing representatives, voters have comprehensive information about their competence on relevant issues and get complete information about how representatives realize their legitimate interests. Based on the full, open, and public information voters receive live feedback, which eliminates any potential meaning for policy mislead voters about their intentions.

Secretariat of the Cabinet of Ministers of Ukraine and the PDP is responsible for the development and application of new mechanisms of public participation in public policy, namely the introduction of an automated diagnostic system of normative legal acts, as well as automated prioritization of regional policy involving the public in the 24 regions of Ukraine, Crimea, Kyiv, and Sevastopol.

\section{An Interactive On-line Platform}

The idea of creating an Internet platform is to provide networking opportunities for the general public from different regions and implement civic engagement through the use of new systems.

Any citizen can register on the site. Personal ratings of registered users grow according to their activity in the use of systems, their comments and suggestions. Increasing user rating provides more features.

Using the implemented system will allow the public councils to assess and make proposals of draft regulations, to express their views on the priorities of regional policy, to be acquainted with the results of incorporation or rejection of their proposals, to read analytical materials, to contact experts from other cities and regions, and to ensure high ranking public council activity as compared to other similar community-level councils that serve as one of the indicators of performance. 
Automated diagnosis of draft legal acts - Internet-oriented software for drafting and coordination with experts and the public.

Users of the on-line platform will have the following options available:

- browsing and searching of draft legal acts submitted for discussion;

- reviewing proposals for draft legal acts by other users;

- reviewing analytical materials that reflect the results of public and expert discussion of draft legislation;

- evaluating and adding suggestions to the draft regulations;

- viewing the results of the proposals submitted by that user;

- ranking of proposals of other users;

- discussing draft legal acts in the virtual expert community.

Representatives of the government system will automate the process of making laws for public and expert discussion and greatly facilitate further analysis and consideration of the results.

Drafters will be able to:

- simplify and accelerate the development of projects by automating many operations and the possibility of collaboration on the project through the network;

- prepare a new version of the draft based on estimates and proposals;

- monitor actions of ranking offers users and experts;

- create documentation for specific reporting templates (comparative tables, reports, etc.);

- use the software package "Logos" to generate in-depth analyzes.

The implementation of the system will provide a significant boost and will facilitate the process of drafting regulations, taking into account the views of experts and the public, it will alsocreate a mechanism to evaluate each element of the draft documents with the ability to further analyze their potential "weaknesses".

The system allows you to receive information via the Internet on certain issues and analyze data in different sections.

Users of the system will be able to:

- assess priorities for their region;

- include proposals for regional policy in different sectors;

- provide an assessment if the local authorities are solving actual problems;

- view the results of evaluation of public regional problems;

- participate in thematic expert surveys.

Examination involves registered experts, including representatives of community councils; in the case of expert surveys by filling out electronic forms developed by analysts on the Internet platform. Expert group for such studies are 
formed depending on the scope of professional knowledge and interests of experts.

After the survey, the data is processed using a variety of methods of mathematical statistics and visualization and serves as a generalized analytical report.

It provides the possibility of formation of analytical reports of two types:

- comparative analysis of regions in separate blocks of problems - for citizens who take part in public discussions;

- in-depth analysis in different sections - for experts and government representatives.

Internet sites of public authorities should ensure:

- surgical placement of information related to the activities of the department, its organizational structure, personnel, address and background information, statutory regulations and standards in regulating the activities of a public authority, information about the agency implemented programs and projects, information about the target and actual indicators of its activity;

- online access to public information contained in departmental information systems;

- publication of information provided by public services and conditions of its production, including regulations, letterheads forms, questionnaires and applications, reference and guidance for their completion and delivery, popular explanations for untrained categories of citizens;

- organization of interaction with citizens in the delivery of public services;

- obtaining feedback and processing appeals.

In order to ensure completeness of the system as well as its operational update, a detailed list of the published information, order, timing and frequency of their location and updates should be provided to Internet users.

Thus for each office a list of information to be disclosed on departmental information systems in real time shall be determined.

A regulatory and technical requirements for functionality and information security websites of public authorities, standards, information exchange and navigation between different sites of public authorities should be identified. Technological and organizational requirements to ensure full, equal and non-discriminatory access to Internet sites of public authorities for all categories of people and organizations, including access to national diasporas, should be formulated. A significant proportion of citizens are people with different disabilities (hearing, vision, mobility restrictions, etc.) for whom electronic forms of interaction are often the most convenient, or even the only means of accessing government services. The requirements must also define the principles of website design with regard to us- 
ing national symbols. In order to fulfill these requirements, guidelines for the organization of the content and operation of the Internet sites of state authorities should be developed.

On an annual basis each state agency must approve a website development plan. The head of the public body must be identified as responsible for the organization of the content and its functioning. Mechanisms to monitor compliance with the established requirements for websites of public authorities should be developed as well as the responsibility of law enforcement officials. To ensure effective organization and subsequent operation of departmental call centers uniform requirements that define the required list and procedures for interaction with citizens should be developed. In order to provide comprehensive support to help people in interaction with the public authorities a single information system should be established.

A single register of public services provided to citizens and organizations with information about the conditions of their production, as well as general information of public reception, reception centers, and public service authorities indicating phones taking time and responsible officials, procedures for appealing actions (inaction) of state authorities in the performance of duties of public service delivery will be the basis of the referral system. The single information system is designed to handle requests from citizens, search and define public authorities responsible for the provision of public services or more information, and bring this information to the applicant in real time. The system includes a single on-line portal and calls center.

In order to increase the convenience of full-time interaction of individuals and organizations with the government multifunctional centers of state and municipal services can be established (Kuksa, 2012). Multifunctional centers are established to ensure the provision of inter-related public services in a "single window". This interagency cooperation necessary for the provision of public services (including necessary approvals, obtaining statements, certificates, etc.) should be carried out without the applicant.

Interaction with citizens and organizations - recipients of state and municipal services - is conducted in person, by phone, by email, via the Internet (including the portal of public services), and through information kiosks (infomats) located in the multipurpose center.

It is necessary to ensure the timely publication of information on the Internet about the state and municipal services provided on the basis of a multi-center. 


\section{Conclusions}

E-government is not a simple technological solution and innovative concept of governance as a lever scale transformation of society. Changing the legal framework, principles of finance and budget, reallocation priority areas of competence of state and social structures, renewal and expansion of value paradigms of social, educational focus is the basis for reengineering government through the creation and development of e-government. Changes should also affect the electoral system and the principles of legislative activities and schemes of control and increase accountability of all branches of the government to citizens and their associations and economic operators. The basis of the corresponding transformations in the government and government agencies is the willingness of citizens and using information technologies in daily life, business, social and educational activities, training and more. This process is initiated jointly by three sectors - government, civil society, and business.

For the purpose of maintenance and technical support of the pilot administration (government) services to the public in electronic form, the introduction of electronic forms of cooperation between local authorities, executive authorities, and citizens of the region, project activities include the introduction of information-analytical support of pilot administrative services in electronic form, namely, providing government - entities providing administrative services necessary means of information (hardware and software) to implement administrative procedures for pilot services configuration of information in the government.

The process of creation and gradual implementation of information democracy solves problems of information resources, namely the creation of information resources for public administration and implementation of the constitutional rights of different categories of information on government services, ensuring efficient use of government information resources of public authorities and public institutions, individuals, and organizations to provide free access to information resources in accordance with the current legislation of Ukraine, the establishment of an adequate regulatory framework, coordination of sectoral and regional government structures for the formation and use of government information resources, procedures and conditions for use, registration, and accounting of public information resources development and ensure the availability of information on the composition and terms of use of information resources, the definition of the powers and duties of public authorities, enterprises and organizations, departments and experts on creation, protection and use of government information resources, the definition of state information resources needed at every level of government, 
for their formation, forms of representation, collection, input, storage, processing, and use of monitoring and updating of information resources, protection of state information resources, control of their integrity and use.

\section{References:}

Баранов, А. (2002) Эмектронное правитемьство в Украине? Будет! КогАа?. Зеркало недели, 1.

Гнатюк, С. Аотримання інформачійнихправ ісвободукраїнськихгромадян:нормативноправове забезпечення і регулятивні важелі. Аналітична записка. Retrieved from: http://www.niss.gov.ua/articles/231/.

Закон України «Про електронні документи та електронний документообіг». (2003). Retrieved from: http://www.e-ukraine.org.ua/index.php?mod=doc_obig.

КАименко, I. В. Аиньов, К. О. (2006). Технології електронного урядування, р. 225.

Концепція (основи державної політики) інформаційної безпеки України. (2001). Національна безпека і оборона, 1, р. 3-59.

Кукса, В. (2002). Е-беспредел е-бюрократии ожидает е-Украину в отсутствие грамотной государственной информационной политики. Зеркало недели, 49.

Кумик, В. (2011). Авадиять років демократичного транзиту. Retrieved from: http:// ua.for-ua.com/authornews/2011/09/28/113259.html.

Митко, А. М. (2010). Засоби масової комунікауї̈ та імідж влади: регіональний аспект, p. 244.

Проект доповіАі Кабінету Міністрів України Верховній РаАі України про стан та перспективи розвитку інформатизації та інформаційного суспікьства в Україні за 2009 рік, Офічійний веб-сайт Аержавного комітету інформатизачї̈ Украӥни. Retrieved from: http://www.dki.gov.ua.

Проект А. Г. Аук’яненка Закону Украӥни «Про Інформауійний суверенітет та інформаційну безпеку Украӥни». Retrieved from: http://www.uacm.kharkov.ua/ukr/ index.shtml?ulaws/usuvetr.htm.

Самоловов, И.С. (2012). Существует ли демократия без либерализма и наоборот?. Retrieved from: http://concept-science.com/blog/polit/58.html.

Хмемьницький, О. О. (2007). Інформачійна культура: Підготовка кадрів до інформауійноїроботи, р. 200.

Donald, G. (2002). Lenihan Realigning Governance: From EGovernment to EDemocracy, p. 28. 